\title{
Experimental Construction of Musical Instruments between 2017 and 2022
}

\section{Jiří Höhn}

Since the year 1996, the National Institute of Folk Culture (henceforth NULK) has been implemented a long-term research project "Folk Handicraft and Folk Arts in the Czech Republic". The aim of this research project is to video-document technological principles of folk handicraft and folk art production in order not only to document them, but mainly to get an important tool for their safeguarding and for the subsequent development, preservation, and dissemination of high-quality craftsmanship in regions, and for lessons organized for those interested in diverse disciplines of traditional handicraft that use materials from renewable sources. Over time, different fields of handicraft have been addressed, beginning with processing of wood, metal and glass up to folk architecture and clothing.

In 2012, another research branch emerged, which was supposed to document the construction of musical instruments used in folk culture. Over time, the documentation included the construction of chiselled-down stringed chordophones - ochlebky, korábek and skřipky [squeaking-fiddle] (2012-2014), bass chordophones - skřipácký-style [squeaking] bass, trumšajt [tromba marina] and double bass (2015-2016), and plucked stringed instruments without neck - kobza and zither (2017-2018). For the period 2020-2022, attention is paid to a group of instruments which mostly were not used as part of musical performance (meaning the relation performer - listener), but whose principal function was to help children pass the time spent with cattle at pasture, to develop children's abilities and phantasy in their games, and to bring children's life nearer to the world of adults. The group includes children's musical instruments, meaning diverse whistles with "snorting" and "buzzing" sound, as well as recorders and shepherd's pipes. In general, these are simple woodwind instruments made by those playing them. Their existence is substantiated by a lot of preserved exemplars and mentions in folk verbal art and folk songs.

In this study, we will deal with kobza, a musical instrument included in the research from 2017-2018, and with experience gained by the experimental construction of aerophones, which was realized in autumn 2020. These musical 
instruments have been chosen as they all feature simplicity of their production using locally available natural sources, predominant use as solo instruments, low demands on tools used, and tonal system influencing also the melody of folk songs.

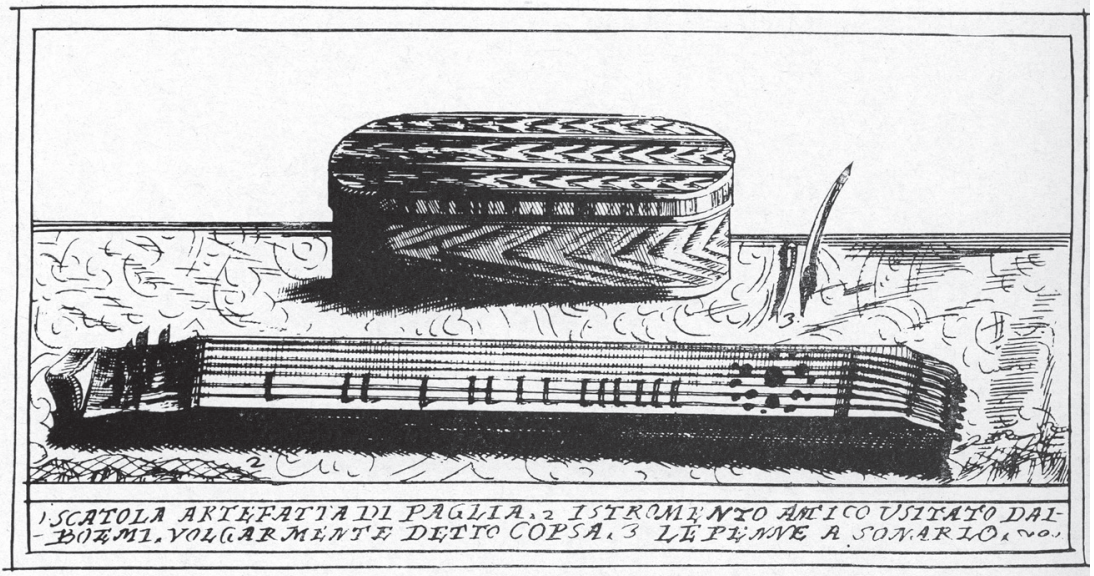

Fig. 1. Drawing of kobza by Earl Jan Rudolf Špork, Museum of Czech Literature (sign. DE III 24, fol. 40), (Volek, Tomislav - Jareš, Stanislav: Dějiny české hudby v obrazech [The History of Czech Music in Pictures], Prague 1977, Fig. 194).

\section{Kobza}

Kobza is a zither-style instrument (the strings are stretched over the sound box and the instrument has no neck). The name kobza can be found in many reports even in the Middle Ages, however, currently we are not able to demonstrate the then form of the instrument. ${ }^{1}$ The first depiction of a musical instrument the construction of which corresponds to that of contemporary kobza, meaning an instrument with a box-shaped structure of the body, can be found in a picture from the year 1740; the picture is accompanied by a note that Czechs use the colloquial term "copsa" for the depicted instrument. The drawing was made by Jan Rudolf Špork (1695 or 1696-1759), a Prague bishop (Fig. 1). The construction of the depicted instrument corresponds to that of contemporary kobza. It features a rectangular shape with frets under three strings, which made melodic playing possible, and several accompanying strings. Due to the depicted round sound holes, it can be deduced that the instrument was completely closed. There

1 Pavel Kurfürst, Hudebni nástroje [Musical Instruments] (Prague: Togga, 2002), 440. 


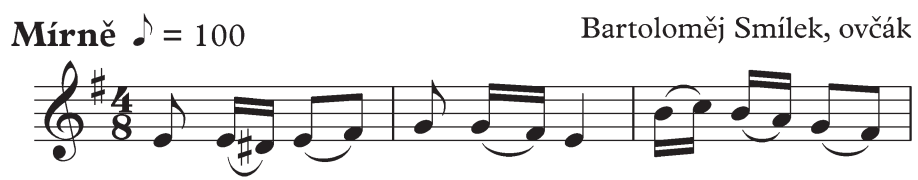

1. Ko- bzin ko, ko- bzin-ko, za - hré mně

2. Deš za - hráš, ko- bzin - ko, pa - nen-ko
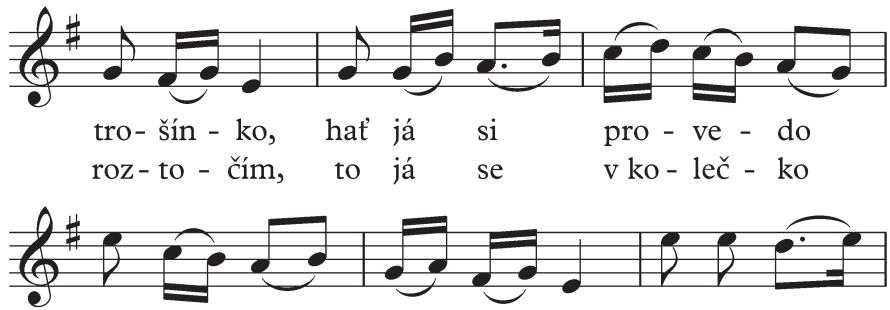

svó mi - ló pa - nen - ko, hat’ já si

z má mí - la za - to - čím, to já se

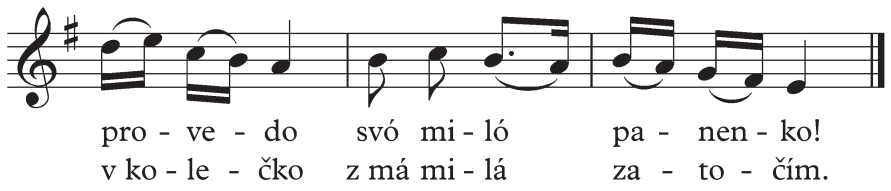

Fig. 2. Transcription of the song from the archives of the Institute of Ethnology of the CAS (Institute of Ethnology in Brno. Sig. A 1163/1165).

is a plectrum depicted above the instrument; its shape allow us to conclude that it is a whalebone.

In the second half of the $20^{\text {th }}$ century opinions occurred which alleged the kobza was only a Wallachian musical instrument. This fallacious interpretation was caused by the fact that the instrument disappeared early and that it survived only in the region of Wallachia until the $20^{\text {th }}$ century. The occurrence of the instrument throughout the Czech Republic is substantiated by plenty of surnames derived from its name - "Kobza, Kobzínek, Kobzař, Kobzík, Kobzáň." Mentions can be found also in songs. For example, the song titled Kobzinko, kobzinko, zabré mně trošinko [ $\approx$ You, small kobza, play a little for me] (Fig. 2), stored in the archives of the Institute of Ethnology of the CAS in Brno, can be found in the Brno area. ${ }^{3}$

2 According to server www.přijmení.cz, 919 persons with the name Kobza/Kobzová, 5 with the name Kobzínek/Kobzínková, 111 with the name Kobzík/Kobzíková, and 47 with the name Kobzáň/Kobzáňová, 0 with the name Kobzař lived in the Czech Republic as of 31 October 2018.

3 Recorded by František Svoboda in Líšeň. The record also includes a note: "Kobza - an old musical 
However, the instrument cannot be considered to be only a Czech or a Slavic phenomenon. The kobza, even with diverse names, is substantiated also in surrounding regions. Ludvík Kunz mentions two names for the Czech and Slovak Republics: kobza-Scheitholt, which is caused by language dualism of German and Czech. He recorded the name "Scheitholt" for contemporary Austria, Switzerland, western Poland, Norway, Sweden, and a part in north-western Hungary. In southern Poland, Slovakia, and predominant part of Hungary, Kunz often found that the term "kobza" was confused with the term "zither". ${ }^{4}$ Pavel Kurfürst specifies the language distribution, mentioned by Kunz. "Identical musical instruments occurred in folk environment almost in the whole of Europe at the same time, but under different names: in Ireland (fidla), in Sweden (hummel), in Norway (lengeik) in Denmark (humle), in Holland (hommel, noordsche balk), and Schitholt in German-speaking European areas."

The instrument was primarily used as a solo instrument, and it often accompanied evening works and small get-togethers. But there are exceptions. For example Joža Ország-Vranecký in his book $A$ mél jsem já piščalenku [And I had a Small Flute...] remembers: "It was not used in combined music, it was to make entertainments, chats, and feather-plucking get-togethers more pleasant; but sometimes, if no other instruments was at hand, it accompanied young people's dance." ${ }^{6}$ A kobza player thus could also accompany a village dance party. An atypical integration of kobza in a music ensemble is described by František Vavák, a village mayor in Milčice: ${ }^{7}$

Někde mnozí se sebrali a všichni najednou hráli, že ta jejich konkordancí divnou měla resonanci:

Dva byli třebas s dudama, zas na housle s valthornama, opět s cimbálem, píštalou, havír s kobzou neb s citharou. Přišel-li pak kolovrátek, ten $\mathrm{v}$ tom ve všem udál zmatek, myslil, že není přes něho, zvýšil schválně hlasu svého, ještě na truc točil druhdy, že př̌nal všech jiných hudby.

instrument similar to the lyre. As to Smilka's information, a kobza was owned by the Traurych family in Lišeň" (Institute of Ethnology, Brno, Sig. A 1163/1165).

4 Ludvík Kunz, "Scheit - Kobza", in: Časopis moravského muzea v Brně II (Brno 1978): 239.

5 Kurfürst, Hudebni nástroje, 440.

6 Joža Ország-Vranecký, A mél jsem já píščalenku [And I Had a Small Flute] (Ostrava 1963), 17.

7 "Somewhere many gathered and all of them played at once, so their concordance had a strange resonance: maybe two of them played together with bagpipes, then again the violin with French horns, again with cimbalom, flute, and a miner with kobza or zither. If a barrel organ player came, he only made a mess, as he thought he is the one and only, he intentionally raised his voice, and he sometimes rotated the barrel organ to drown out the music of all the others. They were angry with him and ordered him to stop, but he turned it into laugh, and over time, he also caused a sin. The farmer and his guests had a good laugh at this. Look, there were many pranks at that time." 


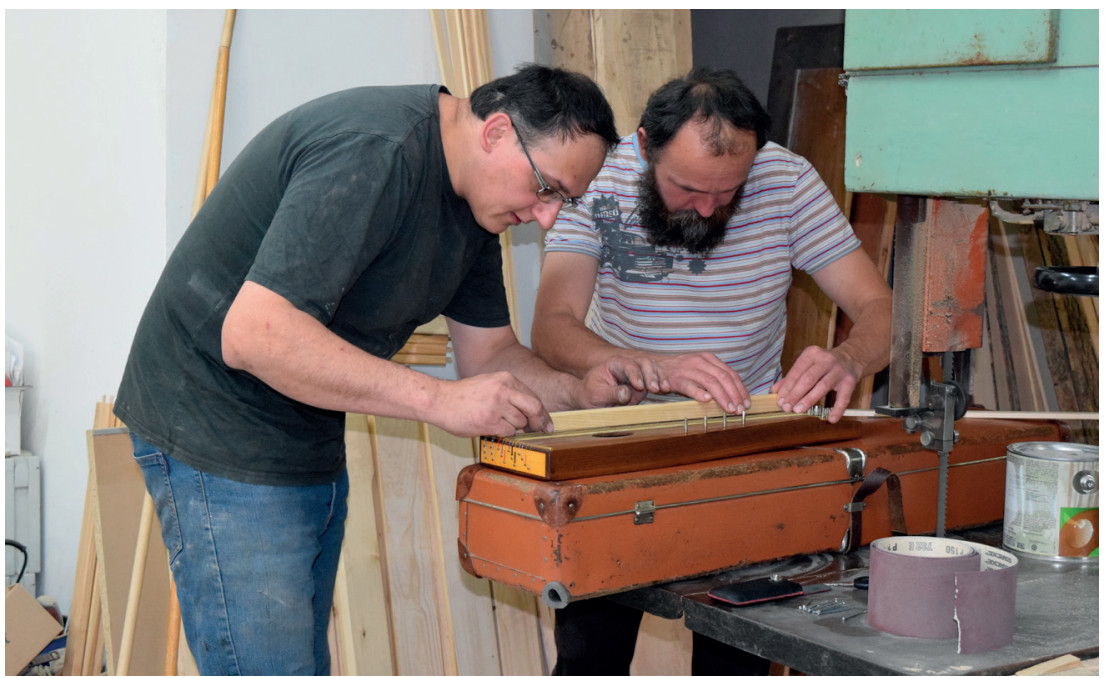

Fig. 3. Jakub Orság and Vít Kašpařík. Photo Jiří Höhn 2018, NULK archives.

Oni se na něj mrzeli, aby přestal, mu veleli, ale on to obrátil v smích, časem $z$ toho pošel i hřích.

Hospodář a jeho hosti nasmáli se při tom dosti.

Hle, i dosti toho času bylo všelijakých špásů. ${ }^{8}$

Kobza disappeared from folk culture during the first half of the $20^{\text {th }}$ century. Although contemporaries and several last musicians were alive even in the $1950 \mathrm{~s}$, František Dobrovolný could only state that the renewal of playing the kobza, and the integration of the instrument into folklore faces several difficulties: "Mainly for the reason that the types of kobza used in our lands do no longer comply with the demands which the performance of most of our songs would impose on them. The other reason is that this instrument disappeared from folk use a long time ago, and we have no model or record how to use it in folk music."

Two production techniques were used for the experimental construction of kobza. Vít Kašpařík made a chiselled-out kobza, and Jakub Orság built a glued kobza (Fig. 3).

8 Jindřich Skopec, Paméti Františka J. Vaváka, souseda a rychtáre Milčickébo z let 1770-1816, kniha druhá (rok 1784-1790) [Memories of František J. Vavák, a neighbour and village mayor in Milčice, from the years 1770-1816, the second book (years 1784-1790] (Prague: Dědictví sv. Jana Nepomuckého, 2019), 9.

9 František Dobrovolný, Lidové hudebni nástroje na Moravě, II. díl (Prague: Ústřední dům lidové tvořivosti 1958), 7. 

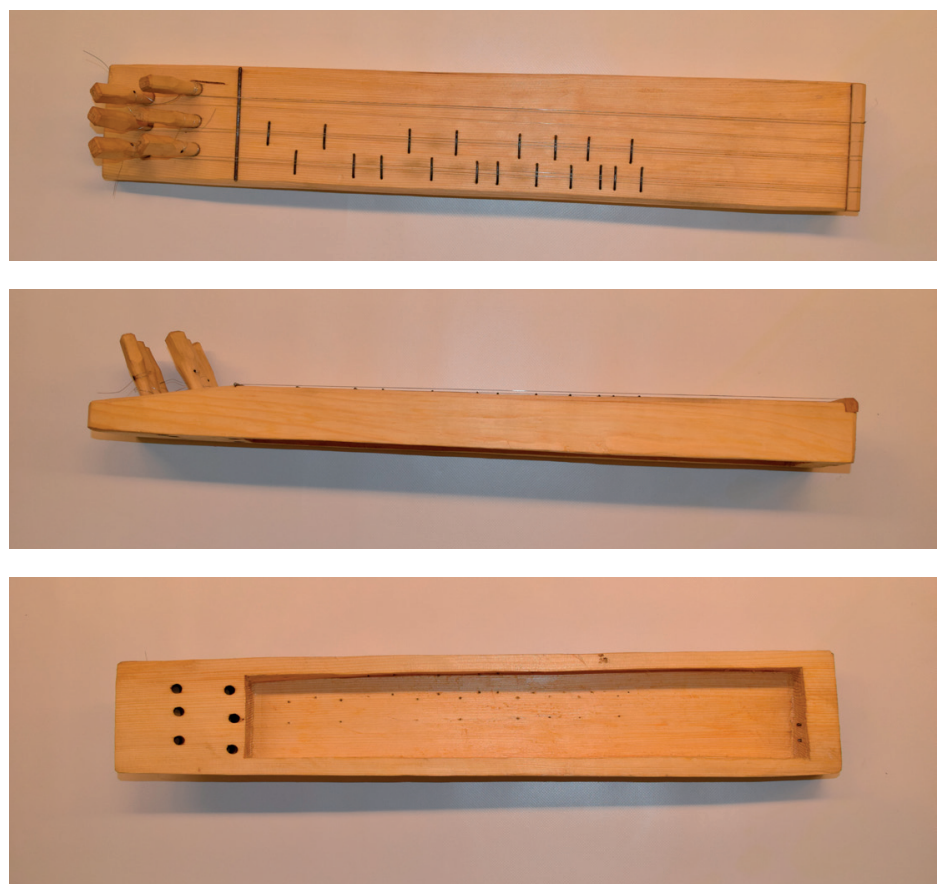

Fig. 4. A kobza with chiselled-out body. Photo Jiří Höhn 2018, NULK archives.

\section{Chiselled-out kobza}

As to its construction, it is among the simplest chordophones. It features a slim body and massive sides. The resulting shape is significantly influenced by the material used (Fig. 4).

The chiselled-out kobza was built based on a presumption to make an instrument which rural residents would have been able to make in the environment of their agrarian life. This thesis proceeds from the knowledge of historical techniques applied in wood processing, and it also reflects the development possibilities or organology, commonly known from other groups of musical instruments.

After the calculation of net time, necessary for the construction of the chiselled-out kobza, it is possible to state that a similar instrument can be built within approx. 12-16 man-hours, when using the documented technique. ${ }^{10}$

${ }_{10} \mathrm{~A}$ man-hour is the amount of work performed by an average person within one hour. It is only a technical quantity that excludes time for relaxing, eating, repairs of damaged equipment, or external influences (for example a soil slide into a trench). For example, for the work done by 
The construction also demonstrated that the tools used can help achieve a smooth surface, which is necessary under the melodic strings and for the functional system of string tuning.

A reduced resistance of the instrument to string tension was a negative finding. After approx. six months, the instrument showed a slight sag caused by strong tension and insufficient natural drying. After a year, also light degradation of the tuning system began to become evident, which was caused by gradual wear and tear of soft wood used for the head, and for this reason it is difficult to tune the instrument.

A digital tuner was used to measure out particular frets, but at trail tuning the producer was able to define an approximate position of frets also by the sound with quite a small deviation. This deviation can be found for example on kobzas, stored in the Wallachian Open-Air Museum in Rožnov pod Radhoštěm.

Based on the gained knowledge, this form of kobza seems to be technologically possible. But due to its sound and mechanical properties, the existence of this musical instrument is debatable.

\section{Glued kobza}

The instrument has been built in a carpenter's manner. The drawing of kobza by Earl Jan Rudolf Špork from the year 1740 and the drawing published in the book Hudebni nástroje [Musical Instruments] by Pavel Kurfürst (Kurfürst 2002, 440) became models for the construction. In contrast to the previous type, the glued body consisted of an upper sound board (spruce) and side boards made of harder material (maple in this case), which has to resist to the tension of strings and head. On its bottom side, the body is closed with a base (Fig. 5). For the construction, the current traditional equipment of carpenter's workshop was used, including machine working. The result allows us to deduce that the instrument can be produced within approx. 4-5 man-hours, in case the machine equipment is used. If only hand tools shall be used, then the estimation is increased for almost twice as much, meaning approx. 7-9 man-hours. ${ }^{11} \mathrm{It}$ is technological breaks required by the applied adhesive that cause the main delay during the production of a glued kobza, whereby at least 2 to 4 hours are necessary in the case of a dispersion adhesive, and up to 12 hours in the case of a glue adhesive.

a group with several people, the total time spent for the activity multiplied by the number of workers is calculated. The result is a period of time for which the work would be performed just by one person. This term was mainly used in experimental archaeology, where it makes it possible to define more exactly a period, necessary to carry out techniques that shall be verified.

11 The estimations based on experience of the producer Jakub Orság. To verify the correctness of this estimation, it will be necessary to build an identical instrument, using only hand tools, in the future. 

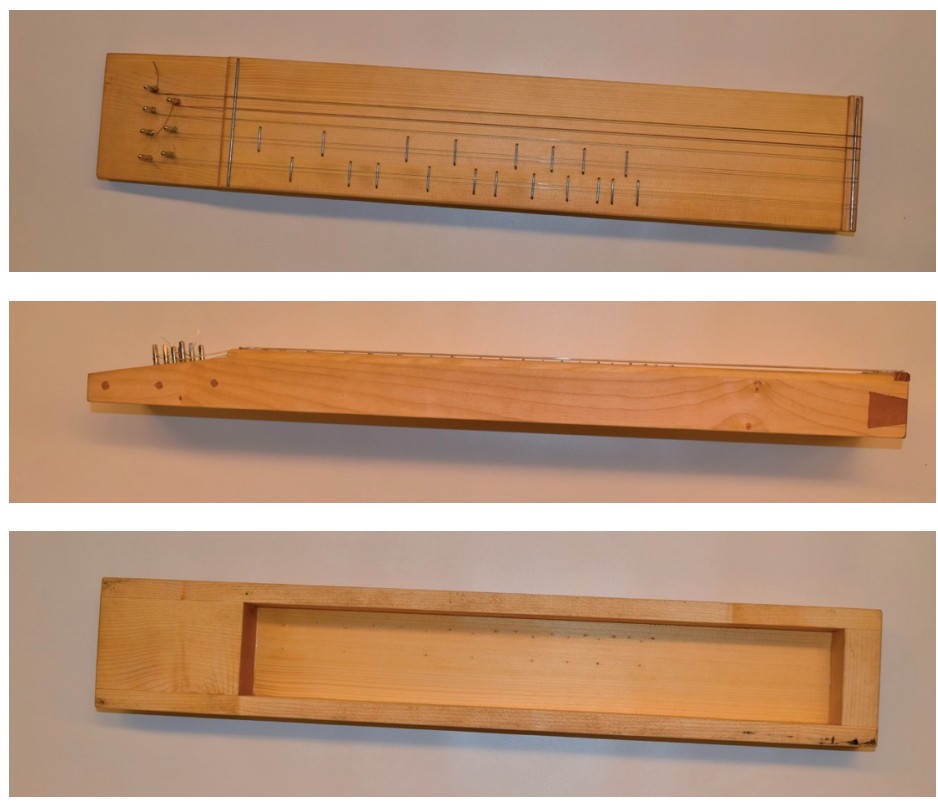

Fig. 5. A kobza with glued body. Photo Jiří Höhn 2018, NULK archives.

In contrast to that, the surface treated with wax dried quite fast; already after 30 minutes it was possible to handle the instrument, but the surface completely hardened after several hours.

Carpenter's constructional elements used for the ribs proved to be resistant to string tension, which was supported by the use of well-dried hard wood. Also the combination of zither tuning pegs and hard material used for the head showed a good influence on the maintenance of tuning during playing. When the instrument was trial-tuned and stored in room temperature for one month (with relatively constant humidity and temperature), it went out of tune only slightly.

\section{Comparison of the results of kobza experimental construction}

Both instruments built within the project feature almost identical dimensions, and also the same tuning was kept (Fig. 6). The hard material used for the sides of the glued kobza made it possible to reduce the thickness of particular parts, to maintain the sufficient firmness of the instrument, and to reduce its weight. The exactness of tuning of both instruments also shows a significant difference. Metal pegs with low diameter, used for the glued kobza, provide finer tuning and 


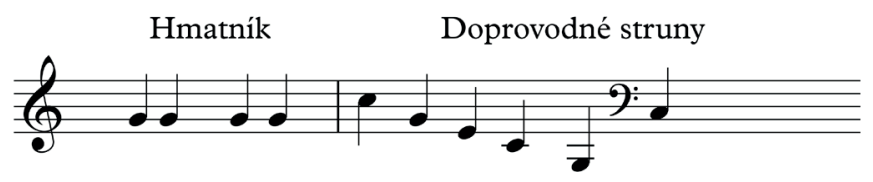

Fig. 6. Tuning of kobza according to Joža Ország-Vranecký.

easier handling then massive wooden pegs used for the chiselled-out instrument. The applied tuning mechanism is also associated with higher intonation stability of the glued instrument, and its resistance to ambient influences.

To verify the quality of sounds, the instruments were played in different environments. It can be said objectively that both instruments show better sound properties if a part of the instrument stands across the table edge. Furthermore, both the listener and the player perceive the playing in a more positive way, if the instrument is played in a small room with wooden floor, which better reflects radiated waves. The carpet and even more the industrial cast floor, which muffled the sound slightly, appeared to be a least suitable surface. The influence of the chosen plectrum on the sound quality was not objectively noticed. In this case, rather user comfort was significant, whereby the guitar plectrum seemed to be more suitable than a quill, a ring, or a bone plectrum.

The command of both instruments seems to be simple, whereby it takes about 30 minutes for a man with elementary knowledge of playing the guitar to learn one song (for example Po valašsky od zemé). Of course, this concerns individual capabilities that will undergo several experiments within educational projects implemented by the NULK.

\section{Simple aerophones}

Simple aerophones are a common link that we can see throughout the human history and almost in all cultures. Simple aerophones from two groups were chosen for the experimental construction in 2020-2022:

a) Edge-blown aerophones (without duct and with duct)

b) Reed aerophones (this part will be implemented in 2021)

Musical instruments stored in the NULK collections were used as the basis for the construction. While creating technologic procedures, the simplicity and availability within the agrarian life of rural residents were taken into consideration. For this reason, a knife and a small saw were used as basic tools. To make 


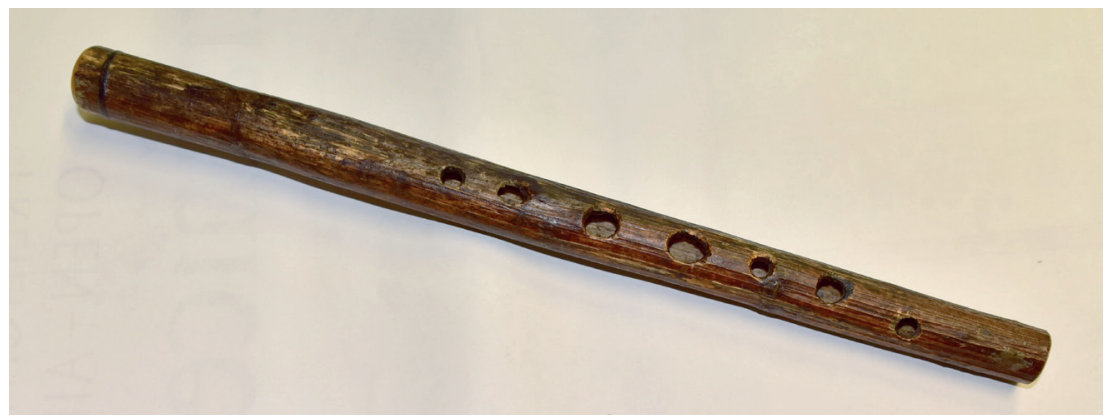

Fig. 7. A whistle made of giant hogweed. Photo Jiří Höhn 2020.

the inside of the tube, common hand augers, used for the production of other farming aids, were used. ${ }^{12}$

Similarly to the tools, emphasis was also laid on the availability of material for the production. The first choice fell on natural hollow materials, such as diverse sorts of reed. This material is stable as to its humidity, and if protected from mechanical damage, quite long lifetime of it can be expected. The narrow diameter of the tube as well as the high brittles around knots as a disadvantage. For this reason, it is not possible to use this material for bigger instruments. Reynoutria and giant hogweed (Heracleum mantegazzianum) stand for suitable building materials. Both plants come from Asia (Fig. 7). They were introduced to Europe as ornamental plants for parks and gardens, but they soon were out of control and began to spread spontaneously. Currently, they are considered to be invasive species and an effort is made to eradicate them. The reynoutria and the giant hogweed feature a hollow stalk with the diameter of up to several centimetres. After having been dried out, the stalks are firm and they can be worked like wood. Thorough desiccation is desired mainly in the case of the giant hogweed which contains phototoxic furanocoumarins (a substance irritating skin and causing blisters even for several months after staining).

Fresh willow twigs are suitable for the production of small instruments. The willow tree, abundant in our lands in the past, can be used only for a short period in the spring where young twigs are full of sap. The sap, running closely under the bark, allows the thin bark to be easily separated from the wood substance. The lifetime of those instrument is not long, the wood dries up quite fast and the air

${ }^{12}$ In 2021, the method of turning-out will be applied, whereby the inside of the tube will be removed by a twisting motion acting on wood core. 
duct is deformed. The tests conducted in spring 2019 showed that the lifetime of a flute can be assumed for one week.

The branches of hazel (Corylus) and elder (Sambucus) are an easily available and better material used for the production of simple aerophones. Both woody plants feature upright-grown and hard wood. The wood substance is easily workable and resistant to mechanical damage and humidity. However, it is not possible to make the instruments from fresh wood; this must dry up for three years optimally, before it reaches suitable humidity and stability. In contrast to the hazel, the elder features soft core, and for this reason it is not necessary to drill the small instruments, but the core can be pushed out using a firm rod. In the case of big instruments, the soft core allows a long auger to be used. This property also allows bent tubes to be made. The lifetime of an instrument directly depends on the quality of working and maintenance. The instruments stored in the NULK collections can be played even after more than thirty years.

\section{Edge-blown aerophones}

Edge-blown aerophones are among musical instruments with simple construction. The sound is created by the explosion of air stream on the edge. The pan flute is an easily buildable representative of duct-free aerophones. We can encounter this type of instruments already in the Ancient culture, where it was, among other things, also a symbol of the Greek god Pan (Fig. 8).

For the project, a five-tone instrument made of reynoutria was chosen. The flutes were made of one stalk (Fig. 9). It was not necessary to provide the tube with a bottom cap, as there is a firm barrier closing the entire inside diameter in the knot. The sound range of the instrument is downwards limited by the maximum distance between particular knots and by stalk diameter. While tuning the instrument, it is necessary to begin with the longest tube, and the others are then tuned by cutting them short. During the experimental construction, the tone at the frequency of $368 \mathrm{~Hz}\left(\right.$ fis $\left.^{1}\right)$ was achieved with the tube length of $228 \mathrm{~mm}$ and inside diameter of $15 \mathrm{~mm}$. The resulting character of the tone corresponds rather to the instrument of South-American origin than to drilled pan flutes, for example from Romania, which are closer to us. The tone of the instrument is round, with a higher content of lower frequencies. While playing, it is always necessary to find a suitable position of the edge against the air stream, which is given by the irregular diameter of the tube. The experimental construction confirmed that it is possible to build the instrument within approximately one hour, using only a small saw and a knife. 

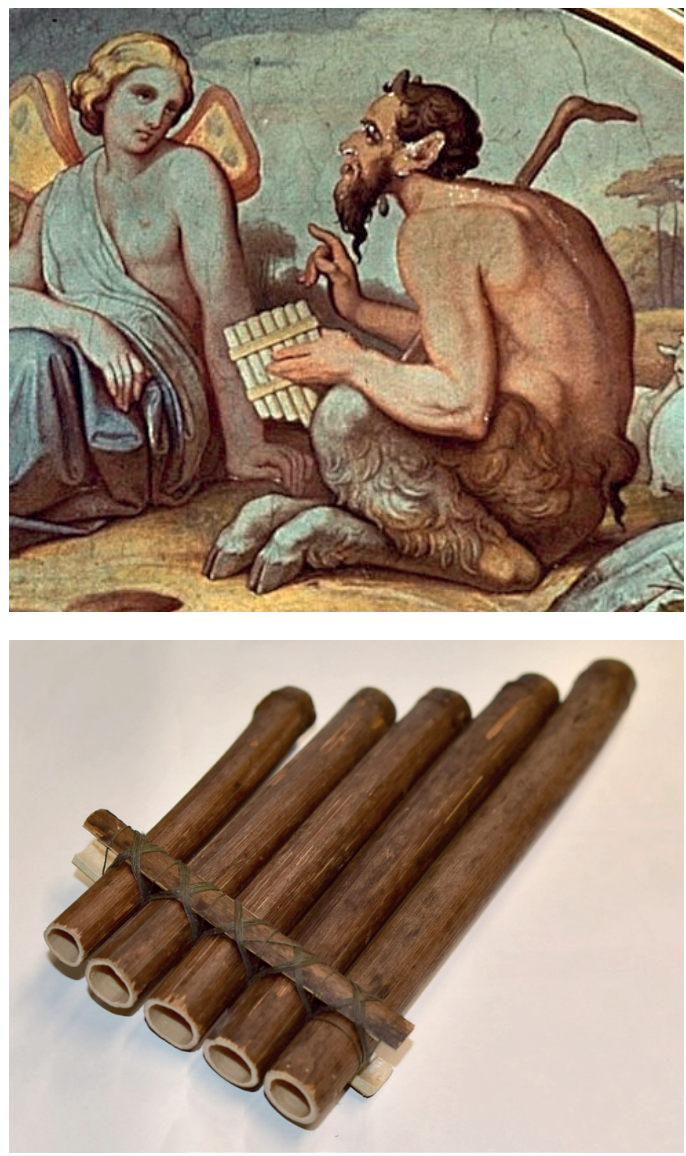

Fig. 8. Pan advises Psyche (detail of Pan). A lunette in the dance hall in the Altenburg Castle by Karl Mossdorf (1823-1891). Online: https://www.zi.fotothek. org/VZ/ort_index/Altenburg\%20 (Thüringen), cit.: 26. 10. 2020.

Fig. 9. A pan flute made of reynoutria. Photo Jiří Höhn 2020.

In almost all culture aerophones can be found, in which the air stream runs against the edge through an air duct (Fig. 10). For this project, the construction of three instruments from this group was documented: a willow whistle, a reed whistle, and an end-blown flute called a koncorka.

The first two are among the group of musical instruments or toys for children. The willow whistle (Fig. 11) is still associated with the spring when children used to make these instruments while pasturing cattle. One needs only a knife to make it. A fresh twig is cut short to the desired length. Then a labium lip is made, and knocking the knife handle on the twig loses the bark. This activity is associated with many children's rhymes, such as: 


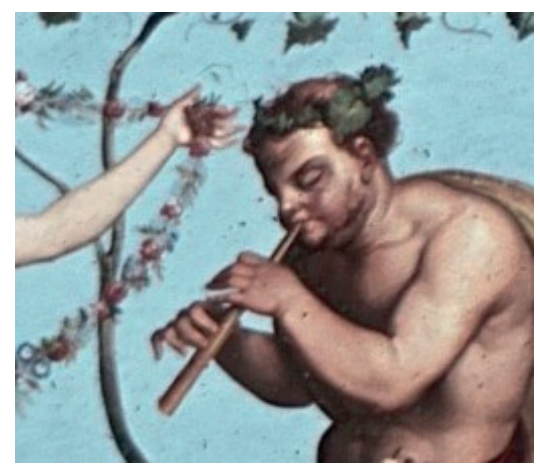

Fig. 10. Education of Bacchus. A ceiling painting in the Rosenstein Castle by Johann Friedrich Dietrich (1787-1846). Online: https://www.zi.fotothek.org/VZ/ort_index/ Cannstatt,\%20Bad, cit.: 26. 10. 2020.
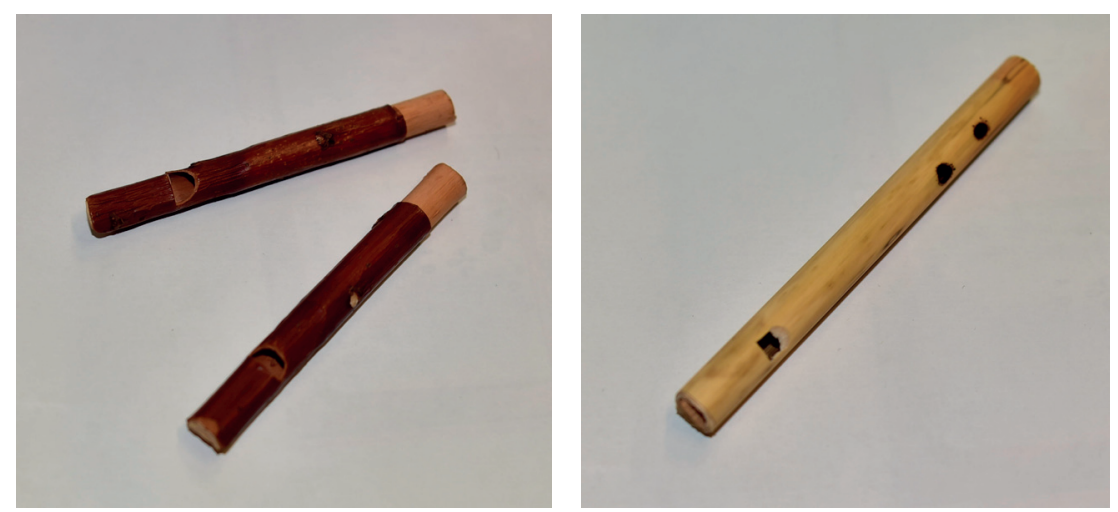

Fig. 11. A whistle made of willow twig. Photo Jiř́ Höhn 2020.

Fig. 12. A reed whistle. Photo Jiří Höhn 2020.

Otloukej se, pištaličko vrbová, nebudeš-li se otloukati, budu na tě žalovati, císaři pánu, ten ti dá ránu, až odletíš k děravému džbánu. ${ }^{13}$

The material removed from the inside is used for making an upper cap and for closing the tube. In this way, a single-tone instrument is produced. It takes

13 "Be knocked, you, a willow whistle, if you do not want to be knocked, I will tell tales on you to our Emperor, and he will punch you so much that you will fly to a leaky jug." A version form the Strážnice area. 
about fifteen minutes to produce one instrument. The lifetime of the willow whistle is about one week, and it depends on drying-up and shrinking of the bark above the air duct.

The whistle made from reed and provided with finger holes is an instrument which is more difficult as to its production, but also more melodic (Fig. 12). Based on the models of "hadrářské" [relating to rag-and-bone men whistles, we chose a short double-hole whistle. These whistles are signal instruments that "using a specific signature tone informed about the arrival of a rag-and-bone man in the village". ${ }^{14}$ For the production we used a reed stalk and we burnt particular finger holes into it, using a glowing piece of wood. The advantage of a burned hole lies in its regular shape. The instrument features an intensive strong tone. The produced instrument has its basic tone at the frequency of $1834 \mathrm{~Hz}\left(\mathrm{~b}^{3}\right)$ with the length of $202 \mathrm{~mm}$ and inside diameter of $6 \mathrm{~mm}$. The position of two holes allows the player to play the range of five tones $\left(b^{3}-c^{4}-d^{4}-e^{4}-f^{4}\right)$. Likewise the willow whistle, also the reed whistle is easy to be made, and it can be finished within thirty minutes. The most time-consuming work is to burn the holes and to fine-tune them.

The end-blown flute, called a koncovka, is the third instrument. According to Ország-Vranecký, this instrument was made by Wallachians ${ }^{15}$ (shepherds) from the trunks of young hazels. ${ }^{16}$ The length of the instrument was derived from the size of the hand to make the playing comfortable. The instrument has no holes, but the melody is created by overblowing two basic tones with opened and closed tube (aliquot tones are used while playing).

Likewise Ország-Vranecký, also Kunz describes two ways of the production. The simpler way, used by us, consists in drilling the body using a long auger. Soft core of the elder leads the auger safety along the middle of the tube. The other way, which is more demanding and suitable mainly for the hazel, is to split the branch into halves radially, and to twist the core wood out of the piece. Then both halves are glued with resin, and tied up with a cord or bark. ${ }^{17}$ This technique will be applied in 2021 .

The tuning of the koncovka is completely random, which is not limiting as it is not played as part of music bands. The tone is sharp and marked by rustle (this rustle can be supressed by smoothing the inside and by treatment with oil). The tone range is limited by the basic tone at low level. This basic tone is not resonant,

\footnotetext{
${ }^{14}$ Kurfürst, Hudebni nástroje, 722.

${ }^{15}$ In this context, the word does not mean "a resident from Wallachia", but residents who live in a territory with predominant pastoral farming.

16 Ország-Vranecký, A mèl jsem já piščalenku, 25.

${ }^{17}$ Ludvík Kunz, Nástroje lidové hudby v Čechách, na Moravè a ve Slezsku, 3. díl [Folk Music Instrument in Bohemia Moravia, and Silesia, 3 Volume] (Rožnov pod Radhoštem 2010), 603-604.
} 


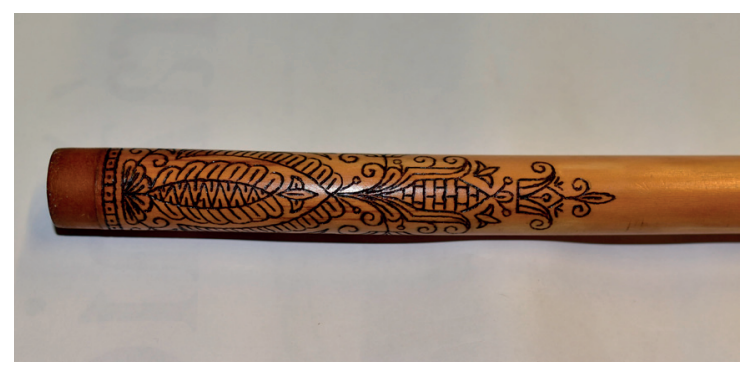

Fig. 13. A detail of koncovka head from the NULK collections, Inv. Nr. 21559. Photo Jiří Höhn 2020.

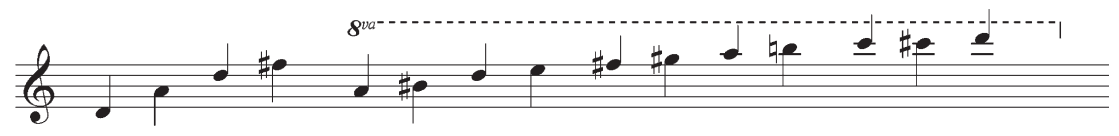

Fig. 14. The tone row of the built koncovka with $D$ as the basic tone. Stems pointing up stand for open bottom hole, stems pointing down stand for closed bottom hole.

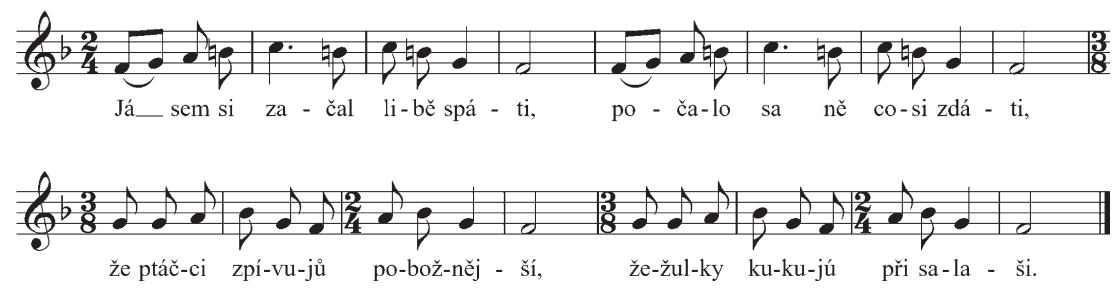

Fig. 15. A Wallachian Christmas carol: Já jsem si začal libě spáti.

and in principle, it is not used when the instrument is played; for this reason it is called "a dead tone". For the melody it is only the first overblowing that is used as a lower tone, meaning the octave of the basic tone. The upper range is limited mainly by player's skills, but in general the third octave above the basic tone is mentioned. The instrument features good lifetime. For this reason, it was common for the producer to embellish his instruments with carving, etching, burning, and metal casting. Figure 13 shows the upper part of a koncovka, decorated with burning and stored in the NULK collections.

The koncovka with its tonal system (Fig. 14) also influenced the melodic aspect of songs. Its range is, for example, a basis for the melody of a dance called odzemek, or of an old Christmas carol Já jsem si začal libè spáti (Fig. 15). The 
koncovka is a successful example of an instrument whose limitation also influences the creation of folk songs.

Within the project, an elder koncovka with the total length of $510 \mathrm{~mm}$ and inside diameter of $11 \mathrm{~mm}$ was made. The frequency of the basic tone is $286 \mathrm{~Hz}$ $\left(d^{1}\right)$. But the first resonant tone sounds only at the frequency of $573 \mathrm{~Hz}\left(d^{2}\right)$. The production was more time-consuming and technologically demanding, and it took about one hour. For the production, only a knife, a saw, and an auger were used, meaning only tools that were available both in the village and in the shepherd's hut.

\section{Conclusion}

The experimental construction made it possible to verify earlier findings from visual analyses of surviving instruments, namely that the researched instruments can be made using basic tools, commonly available in the environment of the agrarian life of rural residents. To build them, there is no need for special knowledge on the construction of musical instruments.

The consultations with producers and musicians also confirmed the suitability of these instruments for diverse forms of music therapy. In addition to the finished instruments, the production stage can be applied as a peculiar educational and, under specific conditions, even healing procedure.

The follow-up stage of the research will include acoustic measurements of the produced instruments, and comparison of the results with instruments preserved in museums. The measurement will be carried out after the other planned musical instrument are finished.

The peer-reviewed essay was written based on the institutional support by the Ministry of Culture of the Czech Republic to the long-term conception of a research organization, the National Institute of Folk Culture.

\section{Experimental Construction of Musical Instruments between 2017 and 2022}

\section{Abstract}

Traditional musical instruments of folk culture quickly disappear from common use and, unfortunately, often from society's general awareness. Mentions about these instruments, contained in songs and surviving in names, are just unknown terms for many people. But in fact these instruments accompanied many generations of our ancestors in their childhood. Although we cannot find any record, 
it is possible to suppose that musical instruments such as willow whistle were one of the first entries into the world of music for many future musicians. More difficult instruments, for example kobza and koncovka, brought musical culture even to regions where people only seldom encountered figural church music, and village dance parties were much poorer in terms of instrumentation. At the same time, these instruments directly influenced the melodies of folk songs.

Despite technical limitations, given by their simple construction, we can perceive their contribution even these days. This concerns for example sound enrichment of current instrumentation, or musical projects based on these instruments (for example the RukyNaDudy music band). As it turns out, these musical instruments (both the kobza, and simple aerophones) show a great potential to be used for the need of music therapy. It is also important that, due to the simplicity of their production, the construction of these instruments can become part of educational system.

We can still draw on the benefit of the transfer of knowledge about the production and playing from musicians and producers, who are still alive. This is the only way to confront the newly built instruments with original models, not only as to their visual and functional aspect.

The above-presented results submit detailed knowledge of the research into kobza in the years 2017-2018 and also first partial results of the construction of simple aerophones from the year 2020. All these instruments are linked to their applicability for music therapy as well as their partial local overlap to the region of the Carpathians.

\section{Experimentální stavba hudebních nástrojů v letech 2017-2022}

\section{Abstrakt}

Tradiční instrumentář lidové kultury velmi rychle mizí z běžného uživání a často bohužel i z povědomí společnosti. Pro mnohé jsou zmínky o těchto nástrojích v písních či pozůstatky ve jménech již jen neznámým pojmem. Přitom tyto nástroje provázely po mnoho generací dětství našich předkủ. Ač nenalezneme žádný záznam, lze předpokládat, že nástroje jako vrbová píštalka byly jedním z prvních aktivních vstoupení do světa hudby pro mnoho pozdějších hudebníkủ. Složitější nástroje, jako např́klad kobza či koncovka, zase vnášely hudební kulturu i do oblastí, kde setkání s figurální chrámovou hudbou bylo minimální a i vesnické zábavy byly, co se týče nástrojového obsazení, mnohem chudší. Zároveň tyto nástroje prímo ovlivňovaly melodiku lidové písně.

Přes technická omezení daná jednoduchou konstrukcí můžeme jejich prrínos vnímat i v dnešní době. Jde například o zvukové obohacení dnešního 
instrumentáře, nebo na těchto nástrojích postavené hudební projekty (např́iklad kapela RukyNaDudy). Zároveň se ukazuje velká možnost užití těchto nástrojů (jak kobzy, tak i jednoduchých aerofonů) pro potřeby muzikoterapie. A co je důležité, díky jednoduchosti výroby, je možné počítat i s aplikací stavby těchto nástrojů v rámci vzdělávacího systému.

Zatím ještě pořád můžeme čerpat $\mathrm{z}$ výhody, jež nám poskytuje kontinuální předávání znalostí o výrobě a hře od dosud žijících hudebníkủ a výrobců. Jedině tak můžeme konfrontovat nově postavené nástroje s původními vzory nejen po vizuální a funkční stránce.

Výše prezentované výsledky předkládají podrobnější poznatky z výzkumu kobzy v roce 2017-2018 a zároveň první dílčí výsledky z realizace stavby jednoduchých aerofonů, která proběhla v roce 2020. Spojujícím prvkem je využitelnost těchto nástrojů $\mathrm{v}$ rámci muzikoterapie a částečně také lokální překryv na oblast Karpat.

\section{Keywords}

Experimental construction of musical instruments; folk handicraft; folk art production; kobza

\section{Klíčová slova}

experimentální stavba hudebních nástrojü; lidové řemeslo; lidové umění; kobza

Jiří Höhn

Národní ústav lidové kultury / National Institute of Folk Culture

jiri.hohn@gmail.com 